\title{
Introduction: the importance of aggregate demand for full employment and rising living standards
}

\author{
Brian K. MacLean, Hassan Bougrine and \\ Louis-Philippe Rochon
}

With an emphasis on developments during and after the Great Recession, and paying due attention to the impacts of austerity policies, the chapters assembled here explain that maintenance of suitably high growth of aggregate demand is as essential as ever to achieving full employment and rising living standards. Written by distinguished Keynesian and Post-Keynesian economists from diverse national backgrounds, the chapters tackle theoretical and empirical issues in an effort to illuminate the economic experiences of both large areas of the world and specific economies.

The volume is organized into three parts, the first of which deals with 'Theoretical Considerations'. The opening chapter by J.W. Mason, on 'Macroeconomic lessons from the past decade', emphasizes the continued relevance of the principle of aggregate demand, first stated in its modern form by J. Maynard Keynes. Mason views aggregate demand deficiency as evidence of a coordination problem, which he identifies as the central economic problem in demand-constrained economies. He draws three lessons for macroeconomic theory and policy of the U.S. experience since 2008. The first is that we should recognize that short-run fluctuations of output and employment are dominated by fluctuations in aggregate demand, not by demographics, technological change or other supply-side phenomena. Second, we should be wary of drawing a sharp distinction between a short run in which growth is demand-determined and a long run in which it is fundamentals-determined. The U.S. experience analysed by Mason suggests that weak growth in employment, productivity and output due to an aggregate demand gap can persist beyond any reasonable definition of the 'short run'. Third, we should realize that the once-orthodox stabilization policy narrowly focused on the central bank manipulating its key policy rate has become untenable. The policy rate is not only a much weaker tool for stabilizing aggregate demand than was widely believed before 2008, 
but central banks must also consider the effects of their actions on asset markets and the distribution of income.

The second chapter by Mario Seccareccia is entitled 'Dualism and economic stagnation: can a policy of guaranteed basic income return mature market economies to les Trente glorieuses?' The 'Trente glorieuses' refers to the golden age of modern capitalism from 1945 to 1975, during which the populations of most developed countries experienced dramatic improvements in living standards due to rapid, income-equalizing growth. The chapter examines proposals both for unconditional basic income (UBI) and for guaranteed annual income cum negative income tax (GAINIT) types of guaranteed income policies, and it considers whether these proposals are sufficient to reverse income polarization in mature industrial economies. The analysis draws intellectual inspiration from Keynes and Karl Polanyi, and highlights the issues involved through use of a diagram representing a hypothetical guaranteed earnings supplementation scheme. While recognizing that guaranteed income programmes have the potential to address the negative consequences of existing social assistance programmes, Seccareccia makes the case that a guaranteed income programme without a commitment to full employment and without floors to market wage deflation could trigger new mechanisms of income polarization.

The third chapter is Jan Toporowski's 'Kaleckian reflections on the wage share in recent Post-Keynesian controversies'. In this short chapter, Toporowski, a biographer of the renowned Polish economist Michał Kalecki (1899-1970), casts a critical eye on two papers routinely cited in Post-Keynesian economics for the claim that inadequate output and employment can be attributed to insufficiency of the wage share. He does not question advocacy of higher wages to equalize the distribution of income, but rather questions the reasoning that attributes economic stagnation to underconsumption and then proposes higher wages as a means to boost consumption and growth. This reasoning is broadly in line with pre-Keynesian views such as those of the Ricardian Socialists and John A. Hobson. Toporowski argues instead for the continued validity of the discovery by Keynes and Kalecki that under-investment is the true cause of economic slumps in capitalist economies, which means that economic recovery requires higher investment or fiscal stimulus.

The second part of the volume provides 'Multi-Country Perspectives'. It deals with aggregate demand and employment issues in large areas of the world and it begins with Malcolm Sawyer's 'The fiscal constraints of the Economic and Monetary Union'. After tracing the evolution of fiscal rules of the Economic and Monetary Union (EMU) from its inception, Sawyer analyses key attributes of the current European 'fiscal compact' that entered into force on 1 January 2013, and provides a detailed critique 
of the compact that, among other things, questions the justification for a specific upper limit on the government debt-to-GDP ratio and the methods of calculating structural government budget balances. Key problems regarding EMU fiscal rules are that their focus is on the size of budget deficits and government debt ratios, and there is no concern with the use of fiscal policy to boost employment through changes to the level of aggregate demand. Euro-area economies have suffered high unemployment for years and 'structural reforms' of labour markets have not worked to reduce unemployment. The core problem has not been labour market rigidity but that the construction of the EMU and its fiscal policy agenda are not conducive to attaining full employment.

The fifth chapter by Matías Vernengo, 'The failure of development in Latin America', discusses the long trajectory of development in Latin America since the 1950s in light of alternative theoretical views regarding the relations among productivity, investment and economic growth, and the implications of these relations for employment. He analyses the fast economic growth during the 1950s and 1960s, the period of import substitution industrialization, followed by the crisis in the 1970s, and the turn to neoliberalism in the Southern Cone. He then moves to the debt crisis of the 1980s, the collapse of growth, and the domination of 'Washington Consensus' policies during the 1991-2002 period. This led to the subsequent election of left-of-centre parties in many countries who rejected the Washington Consensus policies, and through reversal of those policies and the good fortune of higher commodity prices (especially from 2003 to 2008) realized a significant reduction in unemployment and an associated reduction of economic inequality in the region. Finally, Vernengo describes a period after the global financial crisis during which expansionary macroeconomic policy was the norm in Latin America. The period was, however, brief, and he concludes that a grim growth and employment outlook for the near future in Latin America is suggested by the return to conventional fiscal policy in the region combined with the return of the balance of payments constraint in many countries.

The sixth chapter is 'Austerity, unemployment and poverty in developing countries' by Hassan Bougrine and Louis-Philippe Rochon. The authors compare and contrast the experiences of Western economies with those of developing economies. They argue that government intervention played an important role in industrialization of the West, and the rise of the welfare state in connection with the dominance of Keynesian policies produced a golden age of capitalism from the end of the Second World War until the 1970s. By contrast, the industrialization of many of today's developing economies was long hindered by their colonial status, and has been hindered since the 1980 s by austerity policies, often promoted by 
the international financial institutions as keys to long-term growth. These instead have produced economic stagnation and precarious employment. But there are lessons to be had from the exceptional cases in which developing country governments have departed from free-market ideology and stimulated expansion of output and employment through public spending.

The third part of the volume provides 'Country Studies'. It deals with specific national economies - Canada, India and Japan - and begins with Lars Osberg's 'Full employment in Canada in the early 21 st century'. Osberg starts with the observation that while recent annual unemployment rates in Canada may seem low compared to average Canadian unemployment rates since the 1980s, they are actually high when viewed from a longer-term perspective and especially when viewed in light of demographic changes over the past few decades. He proceeds to demonstrate that the decades of high unemployment have been ones in which the goal of full employment has ceased to be one of the stated objectives of Canadian macroeconomic policy. Instead, there has been a policy of avoiding any possible risk of inflation rising above the low inflation target at whatever cost necessary. In an economy where a wide range of unemployment rates is consistent with relatively stable inflation, this amounts to choosing to keep unemployment rates artificially high. Given the economic, political, social and political economy costs that slow growth and high unemployment imply, there is a strong case for the pursuit of full employment interpreted as the lowest possible unemployment rate consistent with relatively stable inflation. This leads Osberg to examine the role that fiscal policy can play in realizing full employment in Canada.

The eighth chapter is Sunanda Sen's 'Employment in India: aggregate demand and structural transformations'. Sen examines the paradox that despite India having experienced high economic growth for some time now, substantial income increases have not been enjoyed by lower-income groups. This is explained in part by employment growth being meagre in relation to output growth, and a lack of initiatives from the state to provide social benefits. Taking into account the large share of the informal sector in India and the structural evolution of the economy, Sen reasons that conventional tight monetary and fiscal policies in India have combined with deregulation of finance to produce a poor record of job creation. A proper explanation of the situation requires both Keynesian aggregate demand analysis and analysis of the structural change in the economy.

The ninth and final chapter of the volume is Brian K. MacLean's 'Abenomics and the Japanese labour market'. MacLean provides background on the adoption of Abenomics by Japan at the end of 2012 and examines the output and labour market impacts of specific policy measures. Japanese economic performance in the previous two decades had not 
been as dismal as it had often been portrayed, but it was characterized by deflation and stagnation that had left Japan's nominal GDP in 2012 at a level 8 per cent lower than in 1997. Real GDP in 2012 was still below its 2007 peak and employment had declined each year since 2009 despite the quantitative easing of the Bank of Japan and government budget deficits that had taken the gross government debt-to-GDP ratio to almost 230 per cent of GDP. There was widespread support among intellectuals that Japan should just accept stagnation as the natural result of population decline and ageing. Yet Shinzo Abe, advised by 'old Keynesian' economists, managed to get elected prime minister with the promise that more expansionary macroeconomic policies would raise output, employment and living standards. MacLean provides evidence for the conclusion that Abenomics has been, on balance, expansionary, and has been successful in overcoming deflation, stimulating growth of output and employment, and producing the tightest labour market in decades.

On balance, the chapters of this volume cover a much greater number of macroeconomic policy failures than policy successes. That is appropriate given the historical record. And a few chapters note that while there was a brief period in late 2008 and in 2009 when a wide range of countries engaged in expansionary policies, it was as if the return to Keynesian policies was in most cases just continued long enough to get national economies through the worst of the global recession, and then policymakers reverted to fiscal conservatism (see Orol 2010), as observed in the accompanying cartoon (Figure I.1).

But the situation is no longer as gloomy as this might suggest. There are at least a few reasons for optimism about growing acceptance of this volume's message that maintenance of suitably high growth of aggregate demand is as essential as ever to achieving full employment and rising living standards.

One reason for optimism is that there has been growing acceptance within orthodox macroeconomics in the past few years that the obsessively anti-inflation stance of much macroeconomic policy is unwarranted. For decades that stance has been justified with reference to the vertical longrun Phillips theory (developed by Milton Friedman and Edward Phelps in the late 1960s; see Palley and Vernengo 2018) combined with empirical estimates of the short-run Phillips curve. While Keynesian and PostKeynesian economists have long questioned the theoretical and empirical foundations of the vertical Phillips curve analysis, in the past few years the empirical evidence that tightening of labour markets does not necessarily raise inflation - the so-called flattening of the short-run Phillips curve has come to be recognized by macroeconomists in general. Contributors to this volume (see also The Economist 2017) are thus able to cite not just 


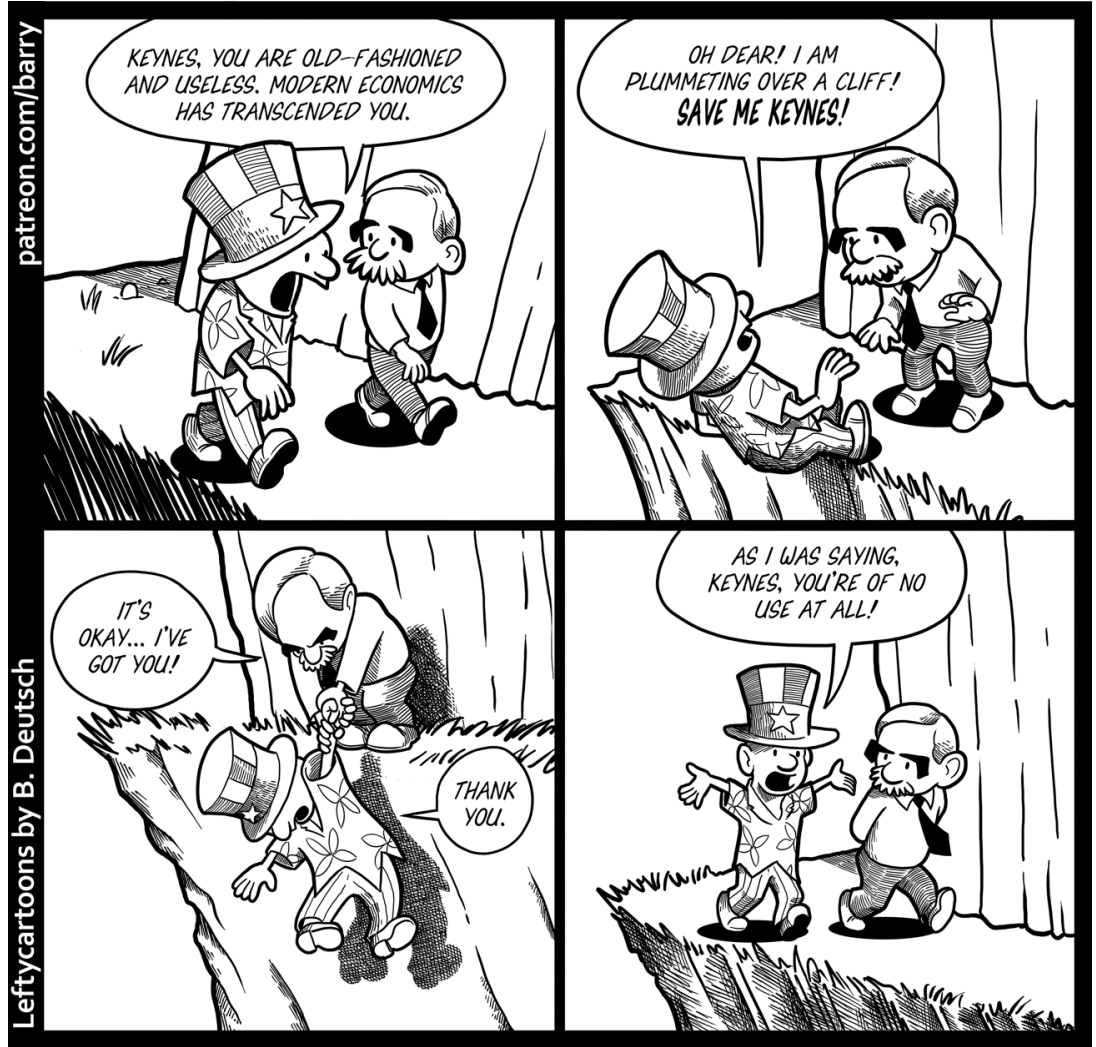

Figure I.1 That useless Keynes

traditional Keynesian and Post-Keynesian criticisms and empirical studies but also more mainstream sources as evidence against macroeconomic policy being obsessed with inflation control and unconcerned with growth of aggregate demand and employment.

A second reason for optimism relates to the recent decline in support by economists for policies of fiscal conservatism. Like extreme anti-inflationism, fiscal conservatism has been a barrier to achieving full employment and rising living standards in many countries. For decades, Keynesian and Post-Keynesian calls for expansionary fiscal policy measures have been countered with fiscal conservative arguments, notably about the crowding out of private-sector investment and the extreme dangers of government debt-to-GDP ratios above some threshold. Evidence from Carmen Reinhart and Kenneth Rogoff, for example, was famously cited in favour of a quick end to the expansionary fiscal policy measures implemented in 
many countries in late 2008 or in 2009 (see, for example, Malcolm Sawyer, Chapter 4, this volume). But in the past couple of years various leading economists have changed their positions on fiscal policy. For example, the former IMF chief economist Olivier Blanchard, who as recently as 2016 had been granting interviews (Evans-Pritchard 2016) on the various risks associated with Japan's rising debt-to-GDP ratio, was by early 2019 the coauthor of a report (Blanchard and Tashiro 2019) arguing that in '. . the current Japanese environment, there is a strong case for continuing to run primary deficits, perhaps even to increase them and to accept a higher debt level'. And even Kenneth Rogoff (2019) criticized the U.K. government for attempting to reduce its 84 per cent government debt-to-GDP ratio.

Of course, the implantation of macroeconomic policies that generate the aggregate demand growth necessary for achieving full employment and rising living standards does not only depend on the ideas held by academic economists. It requires that economists act to ensure that these ideas influence policy-makers and contenders for key policy roles. Here, too, there are reasons for optimism. One example is the rise in influence of Stephanie Kelton (see Carter 2018), an economic advisor to Bernie Sanders' 2016 presidential campaign, and other proponents of the brand of Post-Keynesianism known as Modern Monetary Theory (or MMT). Another example is the campaign spearheaded by Mario Seccareccia, the author of Chapter 2 of this volume, to have the Bank of Canada include a full employment commitment in its mandate. Beginning with a letter in favour of the full employment commitment signed in mid-2018 by the five Canadian contributors to this volume and 56 other Canadian economists including Senator Diane Bellemare, the campaign has so far resulted in a significant amount of coverage in the news media (see, e.g., Macdonald 2018; McKenna 2018; Bellemare 2019); a panel session on the Bank of Canada's mandate at the Canadian Economics Association annual conference co-sponsored by the Progressive Economics Forum and the C.D. Howe research institute; the Minister of Finance Bill Morneau meeting with Mario Seccareccia and other key signatories to hear their views; the Senior Deputy Governor of the Bank of Canada Carolyn Wilkins (2018) mentioning the letter in a speech stating that the full-employment commitment will be one of the proposals to be examined prior to the renewal in 2021 of the Bank of Canada/Department of Finance agreement on the Bank's monetary policy framework; and Senior Deputy Governor Wilkins holding a meeting in May 2019 of several representatives of the Bank of Canada and several prominent supporters of the full-employment commitment.

There are grounds, then, for the editors of this volume to be optimistic that it can be used to contribute to an intellectual and policy environment 
conducive to full employment and rising living standards in countries across the world.

\section{ACKNOWLEDGEMENTS}

We would like to acknowledge the support of our home institution Laurentian University for the project from which this volume originated, and to express our appreciation to all the chapter authors for their timely contributions and to James K. Galbraith for taking time from his busy schedule to provide us with this volume's finely-crafted preface. Brian MacLean would also like to acknowledge his long-standing intellectual debt to the late Michael C. MacCracken (1940-2015), who was a tireless advocate of full employment.

\section{REFERENCES}

Bellemare, Diane (2019), 'The Bank of Canada Act does, in fact, need an overhaul', Globe and Mail, June 10, accessed online July 23, 2019 at: https://www.theglobean dmail.com/business/commentary/article-the-bank-of-canada-act-does-in-fact-ne ed-an-overhaul/.

Blanchard, Olivier and Takeshi Tashiro (2019), 'Fiscal policy options for Japan', Peterson Institute for International Economics, Policy Brief 19-7, accessed online July 23, 2019 at: https://www.piie.com/system/files/documents/pb19-7.pdf.

Carter, Zach (2018), 'Stephanie Kelton has the biggest idea in Washington', Huffington Post, May 21, accessed online July 23, 2019 at: https://www.huffingtonpost.ca/ entry/stephanie-kelton-economy-washington_n_5afee5eae4b0463cdba15121.

The Economist (2017), 'The Phillips curve may be broken for good', November 1, accessed online July 23, 2019 at: https://www.economist.com/graphic-detail/2017/ 11/01/the-phillips-curve-may-be-broken-for-good.

Evans-Pritchard, Ambrose (2016), 'Olivier Blanchard eyes ugly "end game" for Japan on debt spiral', The Telegraph, April 11, accessed online July 23, 2019 at: https://www.telegraph.co.uk/business/2016/04/11/olivier-blanchard-eyes-ugly-end -game-for-japan-on-debt-spiral/.

Macdonald, Neil (2018), 'The Bank of Canada wields enormous power, yet decisions are made in relative secrecy', $C B C$ News, May 30, accessed online July 23, 2019 at: https://www.cbc.ca/news/opinion/bank-of-canada-1.4682521.

McKenna, Barry (2018), 'Getting Canada to that elusive economic "sweet spot", Globe and Mail, June 3: https://www.theglobeandmail.com/business/commentary/ article-getting-canada-to-that-elusive-economic-sweet-spot/.

Orol, Ronald (2010), 'G-20 countries set deficit and debt-reducing goals', MarketWatch (Wall Street Journal), June 27, accessed online July 25, 2019 at: https:// archive.is/20130128111239/http://articles.marketwatch.com/2010-06-27/economy 130783027_1_g-20-deficit-debt-to-gdp-ratio\#selection-465.0-473.14.

Palley, Tom and Matías Vernengo (2018), 'Milton Friedman's presidential address at 50', Review of Keynesian Economics, 6 (4), 419-20. 
Rogoff, Kenneth (2019), 'Never mind the debt: if there's a hard Brexit Britain will have to splash the cash', The Sunday Times, February 3, accessed online July 23, 2019 at: https://scholar.harvard.edu/files/rogoff/files/the_sunday_times_february_ 3_2019_rogoff.pdf.

Wilkins, Carolyn (2018), 'Choosing the best monetary policy framework for Canada', speech delivered by the Senior Deputy Governor of the Bank of Canada at McGill University, November 20, accessed online July 23, 2019 at: https://www. bankofcanada.ca/wp-content/uploads/2018/11/remarks-201118.pdf. 